\title{
The Effects of Self-Control on Internet Immersion : The Moderating Effects of Parenting Attitude
}

\author{
Jea-Ug Ko ${ }^{1}$, Ki-Hyun $\mathrm{Kim}^{2}$, Jin-Ho Jeon ${ }^{3}$ \\ ${ }^{1}$ Professor, Dept. of Social Welfare, Catholic Kwandong University, South Korea, kojea62@cku.ac.kr \\ ${ }^{2}$ Doctor's course, Dept. of Business Administration, Catholic Kwandong University, South Korea, \\ kimkihyun5037@gmail.com \\ ${ }^{3}$ Professor, Dept. of Business Administration, Catholic Kwandong University, South Korea, \\ jhjy@cku.ac.kr \\ Corresponding author: Jea-Ug Ko
}

\begin{abstract}
This study aimed to determine the effects of self-control on Internet immersion in adolescence and the moderating effects of negative parenting attitudes. Furthermore, this study is intended to provide education, prevent Internet immersion, and give parent education so that adolescents could desirably use the Internet. To this end, a survey was conducted on 249 male and female adolescents at the national level. Self-control was used as an independent variable, parenting attitude as a parameter, and Internet immersion as a dependent variable. This study obtained the following results. First, the negative maternal parenting attitude has moderating effects on the impact of self-control on Internet immersion, whereas a negative paternal parenting attitude has no moderating effect. Second, self-control was identified as an essential variable in preventing Internet immersion in adolescence; a significant association was found between maternal parenting attitude and self-control. It is ultimately necessary to improve self-control and maternal child-rearing education at home to solve Internet immersion in adolescence. Furthermorenecessary to get attention and support for maternal education regarding Internet over-immersion in cooperation with schools and communities.
\end{abstract}

Keywords: Self-control, Parenting Attitude, Internet Immersion, Adolescent, Internet

\section{Introduction}

\subsection{Need for Study}

Adolescents, who have poorer self-control than adults, tend to be easily tempted to rely heavily on the Internet and continue to accept information impulsively with no definite idea. Over-reliance on the Internet due to the failure in timing can negatively affect attention development in adolescence. While the Internet, which is available all the time, gives us convenience and enjoyment, it can have an adverse impact due to overuse[1]. Adolescents, who are poor at self-control, are likely to become immersed in a smartphone, and the most frequent cause of smartphone over-reliance was a failure in self-regulation (28.6\%)[2]. It is reported that Internet overuse has made some adolescents neurotic, angry, and sensitive to anxiety[1]. A survey on the use of the Internet in adolescence, which the Ministry of Gender Equality and Family (2020) conducted, found that 228,120 adolescents (17.1\%) formed the over-reliance risk group showing addiction symptoms to the Internet or a smartphone[3].

Received: April 19, 2021; $1^{\text {st }}$ Review Result: June 3, 2021; $2^{\text {nd }}$ Review Result: July 21, 2021

Accepted: August 30, 2021 
Of these, 175,496 adolescents (76.9\%, including overlapped ones) belonged to the Internet overreliance risk group[3]. While the Internet is used to positively form interpersonal relationships as a means of communication in virtual space, it can positively reduce social activity and adversely threaten psychological well-being, called the Internet paradox[4]. In particular, adolescents in a growth phase tend to be at higher risk of mental, social, and emotional sequelae in development due to Internet addiction than adults[5]. Parenting attitude discordance means inconsistent and opposite opinions in parenting. It refers to the lack of consistency in paternal and maternal parenting behavior; such a confusing parenting attitude involves either paternal or maternal parenting behavior, which is inconstant and inconsistent[6]. Inconsistent parenting attitude led to serious Internet immersion; the stronger the control and supervision parents put on Internet use, the more likely adolescents were to get addicted to the Internet. Particularly, the more inconsistent the maternal parenting attitude, the more severe the Internet addiction[7]. Adolescents who were less patient, who showed short-term satisfaction, who were impulsive, and who showed more inadequate attention in terms of self-control got immersed in the Internet quickly; the poorer at self-control one is, the more immersed in the Internet[8]. The delayed outcome with long-term satisfaction or patience, in terms of self-control, can make it less likely to have self-control and impulse control disorders or addiction[9]. It is essential for both parents to be consistent in parenting attitude or behavior; tension and discordance regarding domination and obedience are reportedly strongly correlated with their children's maladaptive behavior[10]. The study on the effects of self-control and parenting attitude on Internet immersion has confirmed that self-control depends significantly on the extent of Internet immersion; thus, the more immersed in the Internet, the poorer at self-control one is. This result implies that the extent of Internet immersion is associated with self-control. Adolescents with poor self-control, who are likely to get addicted to the Internet easily, require attention and control from their parents[11]. Through cyberspace, adolescents experiment and explore a sense of self-identity and introduce and expose themselves boldly. In addition, they meet diverse people, get familiar with strangers freely with no burden, and feel free to express themselves in cyber-space via the Internet[12]. The findings that people immersed in the Internet were less satisfied with their family and social life and that those who were more likely to feel lonely or solitary and who were less aware of social support showed a higher rate of Internet addiction also confirm that social support, which involves family, is an essential factor affecting adolescents[13][14]. On this basis, this study is intended to determine how parenting attitude moderated the effects of self-control perceived by adolescents on Internet immersion.

\subsection{Research Questions}

This study is aimed to answer the following questions:

First, self-control would affect Internet immersion.

Second, a negative paternal parenting attitude would have moderating effects on the impact of selfcontrol on Internet immersion.

Third, a negative maternal parenting attitude would have moderating effects on the impact of selfcontrol on Internet immersion.

\section{Contents}

\subsection{Research Model and Hypotheses}

This study is designed to examine the effect of parenting attitude on the effect of self-control on Internet immersion. 


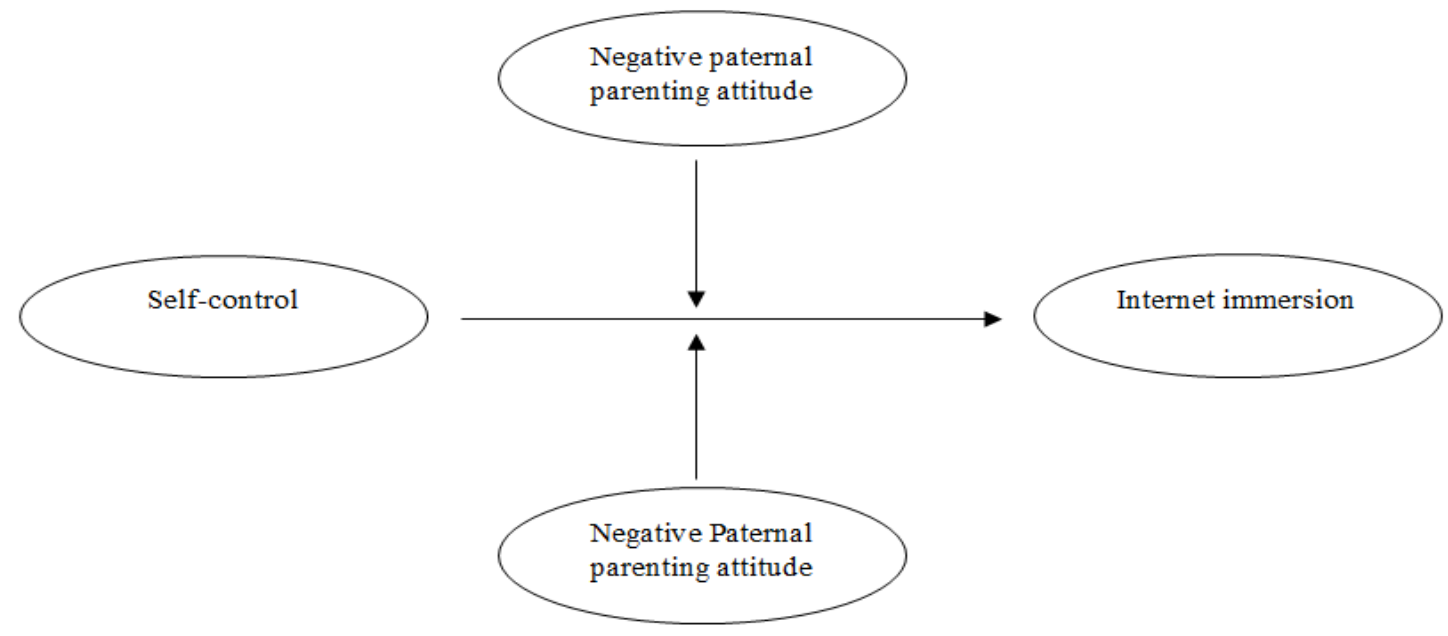

[Fig. 1] Research Methods

H1: Self-control would positively affect Internet immersion.

H2: Negative paternal parenting attitude would have moderating effects on the impact of selfcontrol on Internet immersion.

H3: Negative maternal parenting attitude would have moderating effects on the impact of selfcontrol on Internet immersion.

\subsection{Research Procedure}

An online survey was conducted for two months, starting from March 2020, on 249 college students in the capital area. Questionnaires were distributed to the students willing to participate in the online survey due to COVID-19.

\subsection{Instrument}

\subsubsection{Dependent Variable: Internet Immersion}

The revised version of Young's (1996) Internet addiction inventory was used to measure Internet immersion[4]. It was a five-point Likert scale with a total of 20 items: 6 concerning Internet addiction, 4 concerning social isolation due to Internet use, and 10 concerning academic, physical, and emotional problems accompanying Internet use.

\subsubsection{Moderating Variable: Parenting Attitude}

The revised version of Parker's (1979) Parental Bonding Instrument (PBI) was used to measure parenting attitude[15]. It was a five-point Likert scale with a total of 31 items: 7 concerning parenting abuse and 7 concerning parenting neglect in terms of negative parenting attitude, 7 concerning child's needs in parenting, 9 child's concern, and 3 concerning inconsistent parenting attitude.

\subsubsection{Independent Variable: Self-control}

The revised version of the self-control scale developed by Tangney, Baumeiste, and Boone (2004) was used to measure self-control[16]. It was a five-point Likert scale with a total of 20 items: 10 concerning patient, long-term satisfaction, and 10 concerning impatient, immediate satisfaction. 


\subsection{Data Processing}

The collected data were statistically processed using an SPSS 23.0 program. For the demographic factors of the sample, frequency analysis was performed to estimate frequency and percentage. Confirmatory factor analysis and reliability tests were carried out to validate the variables. To analyze the variables' distribution, descriptive statistics were used to estimate the mean and standard deviation, and inter-variable correlation was determined. For hypothesis testing, structural equation modeling was carried out to determine inter-variable direct and moderating effects.

\section{Results}

\subsection{Demographic Characteristics}

[Table 1] Demographic Factors of Sample

\begin{tabular}{|c|c|c|c|}
\hline \multicolumn{2}{|c|}{ Division } & \multirow{2}{*}{$\begin{array}{c}\text { No. of persons } \\
127\end{array}$} & \multirow{2}{*}{$\begin{array}{c}\% \\
51.0\end{array}$} \\
\hline & M & & \\
\hline Gender & $\mathrm{F}$ & 122 & 49.0 \\
\hline \multirow{5}{*}{$\begin{array}{l}\text { Parent attitude toward } \\
\text { Internet use }\end{array}$} & Very strict & 2 & .8 \\
\hline & Strict & 29 & 11.6 \\
\hline & Average & 91 & 36.7 \\
\hline & Recommending & 124 & 49.8 \\
\hline & Very recommending & 3 & 1.2 \\
\hline \multirow{3}{*}{$\begin{array}{l}\text { The main spot for Internet } \\
\text { access }\end{array}$} & Home & 220 & 88.3 \\
\hline & School & 6 & 2.4 \\
\hline & PC room/Cafe & 23 & 9.2 \\
\hline \multirow{6}{*}{$\begin{array}{l}\text { Internet installation spot at } \\
\text { home }\end{array}$} & One's room & 149 & 59.8 \\
\hline & Parent's room & 6 & 2.4 \\
\hline & Sibling's room & 25 & 10.0 \\
\hline & Living room & 44 & 17.7 \\
\hline & Another spot & 13 & 5.2 \\
\hline & None & 12 & 4.8 \\
\hline \multirow{5}{*}{$\begin{array}{l}\text { Source of help concerning } \\
\text { Internet immersion }\end{array}$} & Parents & 61 & 24.5 \\
\hline & Schoolteacher & 4 & 1.6 \\
\hline & Peer & 74 & 29.7 \\
\hline & School counselor & 10 & 4.1 \\
\hline & $\begin{array}{c}\text { Professional counseling } \\
\text { center }\end{array}$ & 26 & 10.4 \\
\hline
\end{tabular}




\begin{tabular}{|c|c|c|c|}
\hline & Internet search & 49 & 19.7 \\
\hline \multirow{13}{*}{ Mainly used type of Internet } & No help needed & 25 & 10.0 \\
\hline & Information search & 50 & 20.1 \\
\hline & Email & 5 & 2.0 \\
\hline & Personal website & 6 & 2.4 \\
\hline & Online shopping & 10 & 4.1 \\
\hline & Game & 74 & 29.7 \\
\hline & Club & 8 & 3.2 \\
\hline & Chatting & 16 & 6.4 \\
\hline & Messenger & 41 & 16.5 \\
\hline & Download & 3 & 1.2 \\
\hline & Multimedia & 34 & 13.6 \\
\hline & Pornography/Gambling & 1 & .4 \\
\hline & Other & 1 & .4 \\
\hline \multirow{5}{*}{$\begin{array}{l}\text { Daily Internet-using time } \\
\text { (weekday) }\end{array}$} & $<1$ hour & 7 & 3.2 \\
\hline & $1-2$ hours & 41 & 16.5 \\
\hline & 2-3 hours & 63 & 25.3 \\
\hline & 3-4 hours & 78 & 31.3 \\
\hline & $\geq 4$ hours & 60 & 24.1 \\
\hline \multirow{5}{*}{$\begin{array}{l}\text { Daily Internet-using time } \\
\text { (weekend) }\end{array}$} & $<1$ hour & 9 & 3.6 \\
\hline & $1-2$ hours & 26 & 10.4 \\
\hline & 2-3 hours & 58 & 23.3 \\
\hline & 3-4 hours & 49 & 19.7 \\
\hline & $\geq 4$ hours & 107 & 43.0 \\
\hline \multicolumn{2}{|c|}{ Total } & 249 & 100.0 \\
\hline
\end{tabular}

As for the sample's demographic characteristics, $51.0 \%$ of the respondents were male, and $49.0 \%$ female; parents' most frequent attitude toward Internet use was recommendation (49.8\%), followed by average and strict attitudes. The most frequent Internet access site was the home (88.3\%), followed by PC room/cafe and school; the most frequent Internet installation site was one's room (89.8\%), followed by the living room, sibling's room, other, none, and parent's room. The most frequent source of help concerning Internet immersion was peer (29.7\%), followed by parents, Internet search, and professional counseling center. The most frequent Internet use type was game (29.7\%), followed by information search, messenger, and multimedia. The most frequent amount of time for daily Internet 
use on weekdays was 3-4 hours (31.3\%), followed by $2-3$ hours, $\geq 4$ hours, $1-2$ hours, and $<1$ hour. The most frequent amount of time for daily Internet use on weekends was $\geq 4$ hours (43.0\%), followed by 2-3 hours, 3-4 hours, 1-2 hours, and $<1$ hour.

\subsection{Reliability Test for Variables}

Cronbach's alpha for internal consistency was used to determine the variables' reliability; in social science, Cronbach's alpha of $\geq 0.6$ means being reliable.

[Table 2] Reliability Test of Variables

\begin{tabular}{cccc}
\hline & Division & & Cronbach's Alpha \\
\hline \multirow{2}{*}{ Self-control } & Long-term satisfaction & .774 & .823 \\
& Immediate satisfaction & .819 & .934 \\
Internet immersion & Addictive use & .846 & .767 \\
& Social isolation & .877 & .925 \\
& Accompanying problem & .893 & .862 \\
Negative parenting attitude & Abuse & .884 & .856 \\
\hline
\end{tabular}

Cronbach's alpha was estimated at $0.774-0.819$ for self-control, $0.767-0.877$ for Internet immersion, and $0.778-0.893$ for negative parenting attitude. Specifically, every variable was rated $\geq 0.6$ for reliability, and the instrument can be considered reliable.

\subsection{Confirmatory Factor Analysis of Variables}

Confirmatory factor analysis of the variables was performed to validate the observed and latent variables. Goodness-of-fit test as confirmatory factor analysis and the results of the analysis can be analyzed as follows:

[Table 3] Goodness-of-fit Test for Confirmatory Factor Analysis

\begin{tabular}{cccccccc}
\hline Division & $\mathrm{x}^{2}$ & CMIN/df & RMR & GFI & CFI & TLI & RMSEA \\
\hline Model & 153.401 & 1.966 & .044 & .925 & .959 & .945 & .063 \\
\hline Criterion & & $<3.0$ & $<.05$ & $>.09$ & $>.09$ & $>.09$ & $<.08$ \\
\hline
\end{tabular}

If CMIN/df is $\leq 3.0$, RMR is $\leq 0.05$, GFI, CFI, and TLI are $\geq 0.9$, and RMSEA is $\leq 0.08$, goodness-offit is present. In this study, every goodness-of-fit index met the following criteria: $\mathrm{CMIN} / \mathrm{df}=1.966$, $\mathrm{RMR}=0.044, \mathrm{GFI}=0.925, \mathrm{TLI}=0.945, \mathrm{CFI}=0.959$, and RMSEA $=0.064$. The inter-variable relations in this study were found to be valid. 
[Table 4] Results of Confirmatory Factor Analysis

\begin{tabular}{|c|c|c|c|c|c|c|c|c|}
\hline & Path & & $\begin{array}{c}\text { Non- } \\
\text { standardized } \\
\text { coefficient }\end{array}$ & $\begin{array}{l}\text { Standardized } \\
\text { coefficient }\end{array}$ & SE & $\mathrm{t}$ & AVE & $\mathrm{CCR}$ \\
\hline $\begin{array}{l}\text { Long-term } \\
\text { satisfaction }\end{array}$ & $\leftarrow$ & Self-control & .748 & .683 & .106 & $8.323 * * *$ & \multirow{2}{*}{.928} & \multirow{2}{*}{.963} \\
\hline $\begin{array}{l}\text { Immediate } \\
\text { satisfaction }\end{array}$ & $\leftarrow$ & Self-control & 1.000 & .961 & & & & \\
\hline Addictive use & $\leftarrow$ & Internet immersion & .871 & .843 & .041 & $20.692 * * *$ & \multirow{3}{*}{.962} & \multirow{3}{*}{.984} \\
\hline Social isolation & $\leftarrow$ & Internet immersion & .903 & .798 & .044 & $18.373 * * *$ & & \\
\hline $\begin{array}{l}\text { Accompanying } \\
\text { problem }\end{array}$ & $\leftarrow$ & Internet immersion & 1.000 & .994 & & & & \\
\hline Abuse & $\leftarrow$ & $\begin{array}{l}\text { Negative paternal } \\
\text { parenting attitude }\end{array}$ & .787 & .672 & .083 & $9.207 * * *$ & \multirow{5}{*}{.856} & \multirow{5}{*}{.962} \\
\hline Neglect & $\leftarrow$ & $\begin{array}{l}\text { Negative paternal } \\
\text { parenting attitude }\end{array}$ & .792 & .613 & .092 & $8.433 * * *$ & & \\
\hline Demand & $\leftarrow$ & $\begin{array}{l}\text { Negative paternal } \\
\text { parenting attitude }\end{array}$ & .778 & .592 & .093 & $8.316^{* * *}$ & & \\
\hline Attention & $\leftarrow$ & $\begin{array}{l}\text { Negative paternal } \\
\text { parenting attitude }\end{array}$ & .836 & .704 & .085 & $9.574 * * *$ & & \\
\hline Inconsistency & $\leftarrow$ & $\begin{array}{l}\text { Negative paternal } \\
\text { parenting attitude }\end{array}$ & 1.000 & .703 & & & & \\
\hline Abuse & $\leftarrow$ & $\begin{array}{l}\text { Negative maternal } \\
\text { parenting attitude }\end{array}$ & .763 & .692 & .079 & $9.921 * * *$ & \multirow{5}{*}{.882} & \multirow{5}{*}{.973} \\
\hline Neglect & $\leftarrow$ & $\begin{array}{l}\text { Negative maternal } \\
\text { parenting attitude }\end{array}$ & .764 & .763 & .073 & $10.661 * * *$ & & \\
\hline Demand & $\leftarrow$ & $\begin{array}{l}\text { Negative maternal } \\
\text { parenting attitude }\end{array}$ & .881 & .648 & .091 & $9.503 * * *$ & & \\
\hline Attention & $\leftarrow$ & $\begin{array}{l}\text { Negative maternal } \\
\text { parenting attitude }\end{array}$ & .841 & .691 & .088 & $9.932 * * *$ & & \\
\hline Inconsistency & $\leftarrow$ & $\begin{array}{l}\text { Negative maternal } \\
\text { parenting attitude }\end{array}$ & 1.000 & .712 & & & & \\
\hline
\end{tabular}

The confirmatory factor analysis found that the sub-variables of negative parenting attitude, Internet immersion, and self-control statistically significantly accounted for the variables. Convergent validity was at a high level with $\mathrm{AVE} \geq 0.8$, and $\mathrm{CCR} \geq 0.9$, and concept reliability was also high.

\subsection{Descriptive Statistics and Correlation Analysis of Variables}

[Table 5] Descriptive Statistics of Variables

\begin{tabular}{ccccccc}
\multicolumn{2}{c}{ Division } & $\mathrm{N}$ & Mean & SD & Skewness & Kurtosis \\
\multirow{2}{*}{ Self-control } & $\begin{array}{l}\text { Long-term } \\
\text { satisfaction }\end{array}$ & 249 & 3.41 & .63 & -.96 & .91 \\
& $\begin{array}{l}\text { Immediate } \\
\text { satisfaction }\end{array}$ & 249 & 3.82 & .64 & -1.12 & .78 \\
\hline \multirow{2}{*}{ Internet Immersion } & Addictive use & 249 & 3.16 & 1.05 & -.08 & -.57 \\
& $\begin{array}{c}\text { Social isolation } \\
\text { Accompanying } \\
\text { problem }\end{array}$ & 249 & 2.45 & 1.17 & .64 & -.19 \\
\hline
\end{tabular}




\begin{tabular}{|c|c|c|c|c|c|c|}
\hline \multirow{5}{*}{$\begin{array}{l}\text { Negative paternal } \\
\text { parenting attitude }\end{array}$} & Abuse & 249 & 1.77 & .74 & 1.33 & 1.25 \\
\hline & Neglect & 249 & 2.15 & .82 & .73 & .17 \\
\hline & Demand & 249 & 2.44 & .91 & .17 & -.51 \\
\hline & Attention & 249 & 2.42 & .82 & .43 & -.84 \\
\hline & Inconsistency & 249 & 2.49 & .93 & .06 & -.97 \\
\hline \multirow{5}{*}{$\begin{array}{l}\text { Negative maternal } \\
\text { parenting attitude }\end{array}$} & Abuse & 249 & 1.62 & .82 & 1.83 & 1.51 \\
\hline & Neglect & 249 & 1.74 & .71 & 1.23 & 1.28 \\
\hline & Demand & 249 & 2.38 & 1.05 & .35 & -.71 \\
\hline & Attention & 249 & 2.56 & .94 & .09 & -.85 \\
\hline & Inconsistency & 249 & 2.30 & 1.00 & .28 & -.86 \\
\hline
\end{tabular}

The descriptive statistics showed that long-term and immediate satisfaction (3.41 and 3.82, respectively) were rated slightly high for self-control; social isolation (2.45) was rated lowest; addictive use (3.16) was rated highest for Internet immersion. Abuse (1.77) was rated lowest, and inconsistency (2.49) was rated highest for negative paternal parenting attitude, whereas abuse (1.62) was rated lowest, and attention (2.56) was rated highest for negative maternal parenting attitude. Each variable had its skewness and kurtosis within \pm 1.97 , and normal distribution was secured for the variables.

[Table 6] Correlation Analysis of Variables

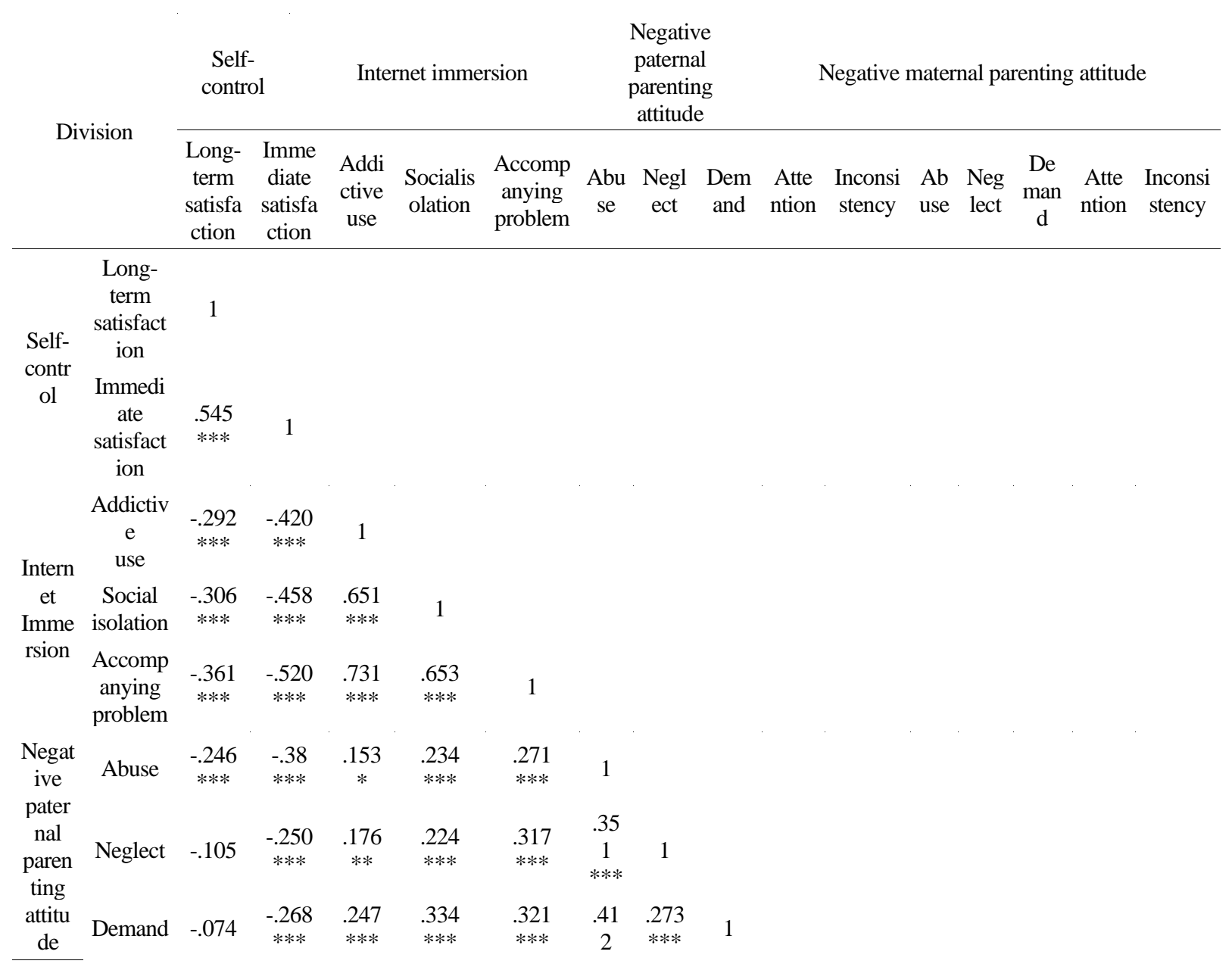




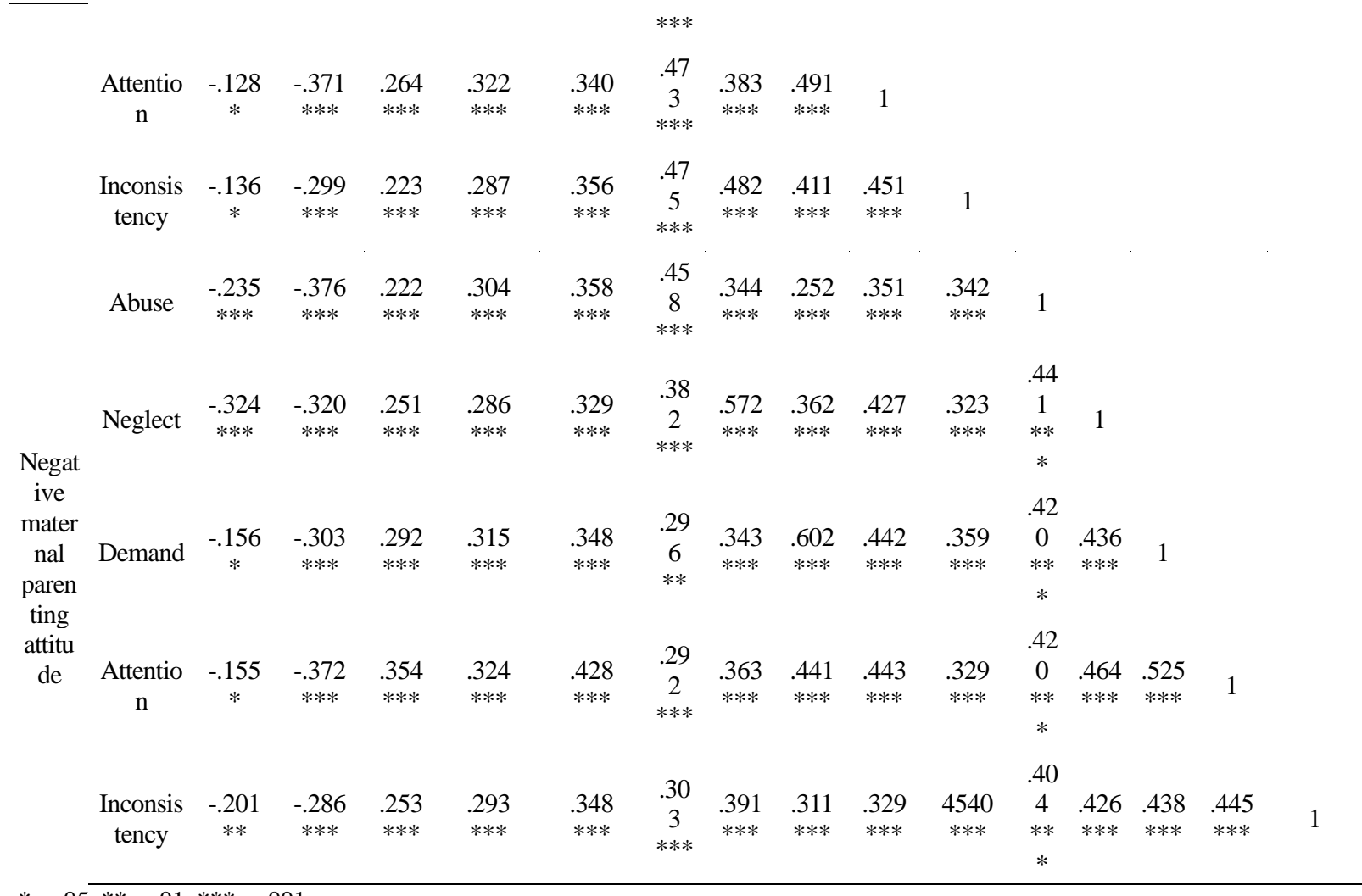

$* \mathrm{p}<.05, * * \mathrm{p}<.01, * * * \mathrm{p}<.001$

The correlation analysis showed that Internet immersion was positively correlated with negative paternal and maternal parenting attitudes and that self-control was negatively correlated with negative paternal and maternal parenting attitudes in most cases. A negative correlation was found between self-control and Internet immersion. Since each variable's direction was consistent with the one set by the researcher, it had discriminant validity.

\section{Hypothesis Testing}

[Table 7] Goodness-of-fit Test of Model

\begin{tabular}{cccccccc}
\hline Division & $\mathrm{x}^{2}$ & CMIN/df & RMR & GFI & CFI & TLI & RMSEA \\
\hline Model & 2.226 & .556 & .010 & .996 & 1.000 & 1.006 & .000 \\
\hline Criterion & & $<3.0$ & $<.05$ & $>.09$ & $>.09$ & $>.09$ & $<.08$ \\
\hline
\end{tabular}

A model's goodness-of-fit is present if CMIN/df is $\leq 3.0$, RMR is $\leq 0.05$, GFI, CFI, and TLI are $\geq 0.9$, and RMSEA is $\leq 0.08$. In this study, every goodness-of-fit index meets the criteria-CMIN/df $=0.556$, $\mathrm{RMR}=0.000, \mathrm{GFI}=0.996, \mathrm{TLI}=1.006, \mathrm{CFI}=1.000$, and $\mathrm{RMSEA}=0.000$ - and the model is considered valid.

[Table 8] Effects of Self-control on Internet Immersion

\begin{tabular}{|c|c|c|c|c|c|c|c|}
\hline & Path & & $\begin{array}{c}\text { Non- } \\
\text { standardized } \\
\text { coefficient }\end{array}$ & $\begin{array}{c}\text { Standardized } \\
\text { coefficient }\end{array}$ & SE & $\mathrm{t}$ & $\mathrm{p}$ \\
\hline $\begin{array}{l}\text { Internet } \\
\text { Immersion }\end{array}$ & $\leftarrow$ & Self-control & -1.373 & -.594 & .195 & $-7.046 * * *$ & .000 \\
\hline
\end{tabular}


Self-control negatively affected Internet immersion $(\mathrm{t}=-7.046, \mathrm{p}<0.001)$; that is, the better at selfcontrol, the less immersed in the Internet.

Structural equation modeling was used to analyze the moderating effects of parenting attitude on the impact of self-control on Internet immersion. When self-control and parenting attitude act as independent variables and Internet immersion as a dependent variable, the interaction term's statistical significance entails moderating effects.

[Table 9] Moderating Effects of Parenting Attitude

\begin{tabular}{|c|c|c|c|c|c|c|}
\hline \multicolumn{2}{|c|}{ Division } & $\begin{array}{c}\text { Non- } \\
\text { standardized } \\
\text { coefficient }\end{array}$ & $\begin{array}{l}\text { Standardized } \\
\text { coefficient }\end{array}$ & SE & $\mathrm{t}$ & $\mathrm{p}$ \\
\hline \multirow{2}{*}{ Internet Immersion } & $\begin{array}{c}\text { Self-control } \\
\text { *negative paternal } \\
\text { parenting attitude }\end{array}$ & -.067 & -.116 & .034 & -1.955 & .051 \\
\hline & $\begin{array}{c}\text { Self-control } \\
\text { *negative maternal } \\
\text { parenting attitude }\end{array}$ & -.078 & -.130 & .040 & $-1.975^{*}$ & .048 \\
\hline
\end{tabular}

$*_{\mathrm{p}}<.05$

As for the moderating effects of negative parenting attitude on the impact of self-control on internet immersion, the interaction between self-control and negative paternal parenting attitude was not statistically meaningful ( $\mathrm{t}=-1.955, \mathrm{p}>0.05)$. Interaction between self-control and negative maternal parenting attitude was statistically meaningful $(\mathrm{t}=-1.975, \mathrm{p}<0.05)$. Negative maternal parenting attitude had moderating effects on the impact of self-control on Internet immersion, whereas negative paternal parenting attitude had no moderating effect.

\section{Conclusions}

This study is intended to provide education, prevent Internet immersion, and give parent education so that adolescents could desirably use the Internet. As for the effects of parenting attitude on the impact of self-control perceived by adolescents on their Internet immersion, self-control negatively affected Internet immersion ( $\mathrm{t}=-7.046, \mathrm{p}<0.001)$; that is, the better at self-control, the less immersed in the Internet. It is necessary to provide various types of programs and education to improve self-control in adolescence. It was found that the better at self-control, the lower the level of Internet immersion, and that improved self-control lowered the level of Internet immersion. Second, as for the moderating effects of self-control on the impact of self-control on Internet immersion, interaction between selfcontrol and negative paternal parenting attitude was not statistically meaningful $(\mathrm{t}=-1.955, \mathrm{p}<0.05)$. Third, the interaction between self-control and negative maternal parenting attitude was statistically meaningful ( $\mathrm{t}=-1.975, \mathrm{p}<0.05)$. This result implies that a negative maternal parenting attitude has moderating effects on the impact of self-control on Internet immersion, whereas a negative paternal parenting attitude has no moderating effect. As for guidance and parenting for adolescents at home, since mothers spend more time in their children's education, maternal parenting draws more attention than paternal parenting. Ultimately, a negative maternal parenting attitude has moderating effects on the maternal impact on Internet immersion, whereas a negative paternal parenting attitude has no moderating effect. Self-control perceived by adolescents was significantly correlated with negative maternal parenting attitude and also affected Internet immersion. Also, it is necessary to run a selfcontrol improvement program and give desirable maternal education at home and at school to prevent Internet immersion in adolescence. Thus, it is important to get attention and support for maternal education regarding Internet over-immersion in cooperation with schools and communities. There is a 
limit to generalizing the study sample to all adolescents, and it did not reflect the actual parenting attitude of the parents.

\section{References}

[1] J. Ahmadi, A. Amiri, A. Ghanizadeh, M. Khademalhosseini, Z. Khademalhosseini, Z. Gholami, M. Sharifian, Prevalence of Addiction to the Internet, Computer Games, DVD, and Video and Its Relationship to Anxiety and Depression in a Sample of Iranian High School Student, Iranian Journal of Psychiatry and Behavioral Sciences, (2014), Vol.8, No.2, pp.75-80.

[2] National Information Society Agency, 2017 The survey on smart phone overdependence, Korea: MIST and NIA, (2017)

[3] http://www.mogef.go.kr/nw/rpd/nw_rpd_s001d.do?mid=news405, Aug 25 (2020)

[4] R. Kraut, J. Patterson, V. Landmark, S. Kiesler, T. Mukopadhyay, W. Scherlis, Internet paradox: A social technologythat reduces social involvement and psychological well-being, The American Psychologist, (1998), Vol.53, No.9, pp.1017-1031.

[5] V. Brenner, Psychology of computer use: XLVII parametersofinternetuse, abuse and addiction: The first 90 days of the Internet Usage Survey, Psychological Reports, (1997), Vol.80, No.3, pp.879-882.

[6] A. T. Beck, The development of depression: A cognitive model, In Friedman, The psychology of depression: Contemporary theory and research, UK: John Wiley \& Sons, (1974)

[7] H. S. Park, The Factors affecting onInternet Addition in Adolescence and how to dealwith it - Focusing on Ecosystem Theory, Journal of the Korea Society of Computer and Information, (2010), Vol.15, No.8, pp.193-200.

[8] S. Y. Kim, S. Y. Choi, B. S. Kim, The Impact ofSelf-Consciousness,Stress, and Internet Use Control on InternetAddiction Among Adults, Journal of Information Technology Serveices, (2007), Vol.6, No.3, pp.47-67.

[9] H. Y. Cho, A Study on the JuvenileInternet Game Addiction andPersonalityTraits, Hanyang University, Master' Thesis, (2001)

[10] G. R. Mussen, B. N. Conger, Delinquents' perceptions of their parents, Journal of Consulting Psychology, (1965), Vol.29, No.6, pp.592-593, DOI: 10.1037/h0022776

[11] S. G. Ahn, H. H. J, Relationship between middle school students and self-control power, The Korean Educational Practice Research Society, (2007), Vol.6, No.2, pp.87-103.

[12] http://users.rider.edu/ suler/psycyber/index.html, Aug 1 (1998)

[13] Y. H. Choi, B. D. Suh, E. H. Choi, Stress and social support according to internet addiction, Journal of Korean Academy of Community Health Nursing, (2007), Vol.18, No.3, pp.452-459.

[14] H. K. Chung, K. H. Kim, Internet addiction, social support and psychological factors in adolescents, Korean Journal of Child Health Nursing, (2004), Vol.10, No.4, pp.406-412.

[15] G. Parker, H. Tupling, L. B. Brown, A Parental Bonding Instrument, British Journal of Medical Psychology, (1979), Vol.52, No.1, pp.1-10.

[16] J. P. Tangney, R. F. Baumeister, A. L. Boone, High self-control predicts good adjustment, less pathology, better grades, and interpersonalsuccess, Journal of Personality, (2004), April, Vol.72, No.2, pp.271-324. 